\title{
Explorasi dan Studi Komposisi Botani Gulma di Perkebunan Karet PTPN IX Kebun Getas sebagai Pakan Ternak Ruminansia
}

\section{Exploration and Study of The Botanical Weeds Composition in Rubber Plantation PTPN IX Getas Farm as Ruminants Feed}

\author{
Harwanto $^{1) *}$, Bambang Suwignyo ${ }^{2)}$, Zaenal Bachruddin ${ }^{2)}$, Galih Pawening ${ }^{2)}$ \\ ${ }^{1)}$ Fakultas Peternakan, Universitas Jenderal Soedirman, Purwokerto, 53122 \\ ${ }^{2)}$ Fakultas Peternakan, Universitas Gadjah Mada, Yogyakarta, 55281
}

Article history

Received: Aug 5, 2020;

Accepted: Jan 10, 2021

* Corresponding author:

E-mail:

harwanto.fapet@unsoed.ac.id

DOI:

10.46549/jipvet.v11i1.133

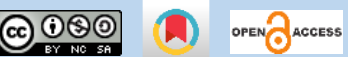

Abstract

Weed is one of the plants that grow around rubber plantations that have the potential to provide forage for ruminant feed. This study aimed to explore the environmental conditions and identify the botanical composition of weeds under the shade of rubber trees in immature plants (IP) at PTPN IX, Getas Farm, Semarang, Central Java. Exploratory research was conducted to identify the botanical composition of weeds in three IP groups, such as 1-2, 3-4, and 5-6 years old. The composition of the weeds' botany was divided based on the plants' morphology into grass, legume, forbs, and browse. The environmental conditions data were analyzed using the ANOVA method and followed by Duncan's Multiple Range Test. The botanical composition data were tabulated using a summed dominance ratio. The results showed the light intensity, wind speed, environment temperature, and weed botanical composition decreased as the rubber plants ages. The composition of rubber plantation weeds on IP 1-2 years old consisted of 32 species ( 5 kinds of grass, 4 legumes, 21 forbs, and 2 browse). The composition of weeds on IP 3-4 years old consisted of 15 species ( 8 kinds of grass, 2 legumes, and 5 forbs), while IP 5-6 years old consisted of 6 species (4 kinds of grass, 1 legume, and 1 forb). The dominant weeds of each IP were Calopogonium mucunoides, Cyrtococcum acrescens, and Cyrtococcum oxyphyllum, respectively. Based on the results of the study it was concluded that the area of IP 1-2 years old rubber plantation weeds has the highest botanical composition and potential as ruminant feed.

Keywords: Environmental conditions; Immature plants; Rubber plantation; Weed

\section{Abstrak}

Gulma merupakan salah satu tanaman yang tumbuh di sekitar tanaman perkebunan karet yang berpotensi sebagai penyedia hijauan pakan ternak ruminansia. Penelitian ini bertujuan untuk mengeksplorasi kondisi lingkungan pertumbuhan gulma dan mengidentifikasi komposisi botani di bawah naungan pohon karet pada tanaman belum menghasilkan (TBM), di PTPN IX, Kebun Getas. Semarang, Jawa Tengah. Penelitian dilakukan secara eksploratif terhadap kondisi lingkungan dan identifikasi komposisi botani gulma pada 3 kelompok TBM yaitu umur 1-2; 3-4; dan 5-6 tahun. Komposisi botani gulma dibagi berdasarkan morfologi tanaman yaitu rumput, legum, forb, dan browse. Data kondisi lingkungan kelompok TBM dianalisis menggunakan ANOVA dan diuji lanjut menggunakan Duncant's Multiple Range Test. Data dominasi komposisi botani ditabulasi menggunakan summed dominance ratio. Hasil penelitian menunjukkan intensitas cahaya, kecepatan angin, suhu lingkungan, dan komposisi botani gulma menurun seiring bertambahnya umur tanaman karet. Komposisi gulma perkebunan karet pada TBM 1-2 terdapat 32 spesies meliputi 5 rumput, 4 legum, 21 forb, dan 2 browse; TBM 3-4 terdapat 15 spesies meliputi 8 rumput, 2 
legum, dan 5 forb, sedangkan TBM 5-6 terdapat 6 spesies meliputi 4 rumput, 1 legum, dan 1 forb. Gulma yang mendominasi masing-masing TBM yaitu Calopogonium mucunoides, Cyrtococcum acrescens dan Cyrtococcum oxyphyllum. Berdasarkan hasil penelitian disimpulkan gulma perkebunan karet lahan TBM 1-2 memiliki komposisi botani dan potensi tertinggi sebagai pakan ternak ruminansia.

Kata kunci: Gulma; Kondisi lingkungan; Perkebunan Karet; TBM.

\section{Pendahuluan}

Kebutuhan pakan ternak ruminansia dipenuhi dari hijauan sebagai sumber serat dan konsentrat sebagai karbohidrat terlarut dan protein. Namun demikian seiring dengan laju peningkatan penduduk, lahan penghasil hijauan semakin terbatas sehingga mempengaruhi perkembangan usaha peternakan. Sehubungan dengan hal itu diperlukan lahan alternatif penyedia hijauan untuk ternak ruminansia yang terintegrasi dengan bidang pertanian ataupun perkebunan. Salah satu lahan potensial yang dapat dimanfaatkan sebagai penyedia hijauan pakan ternak ruminansia adalah intergrasi lahan perkebunan tanaman tahunan karet yang ada di PT Perkebunan Nusantara IX (PTPN IX). Santosa (2017) menyatakan PTPN IX area Getas-Salatiga hingga tahun 2016 mempunyai lahan perkebunan karet sebesar 1544 Ha. GAPKINDO (2016) menyatakan bahwa pada tahun 2013-2014 terjadi estimasi peningkatan luas perkebunan karet dari $3.556 .000 \mathrm{Ha}$ menjadi 3.606.000 Ha. Lahan perkebunan karet memiliki potensi dari tanaman liar yang tumbuh di area perkebunan, yang umumnya menjadi pengganggu dari tanaman utama.

Tanaman karet di Perkebunan Nusantara IX terbagi menjadi 2 yaitu tanaman menghasilkan (TM) dan tanaman belum menghasilkan (TBM). Tanaman menghasilkan merupakan tanaman karet yang telah menghasilkan produksi getah karet dengan umur tanaman lebih dari 5 tahun, sedangkan tanaman belum menghasilkan merupakan tanaman karet yang belum berproduksi, atau belum diambil getah karena masih dalam masa pertumbuhan yaitu umur 0 hingga 5 tahun (Santosa, 2017). Gulma merupakan salah satu tanaman yang dapat tumbuh di sekitar tanaman perkebunan karet dan di bawah naungan tanaman utama. Karakteristik utama gulma bersifat agresif dan persisten yaitu mempunyai pertumbuhan vegetatif yang cepat, mampu memperbanyak secara efisien, kemampuan bertahan hidup dan beradaptasi yang tinggi (Soejono et al., 2000). Gulma bagi tanaman inang dapat menjadi kompetitor, bahkan keberadaannya hampir tak terhindarkan sehingga tanaman gulma menjadi permasalahan tersendiri di area perkebunan. Di sisi lain gulma bagi sektor peternakan memiliki potensi sebagai penyedia hijauan pakan ternak yang mudah diperoleh dan tersedia secara kontinyu sebanding dengan luas area perkebunan.

Vegetasi gulma yang tumbuh dibawah area perkebunan karet dapat terdiri dari rerumputan, tanaman kacangan, tanaman berdaun lebar maupun tanaman pakuan. Tanaman kacangan penutup tanah (legume cover crop/LCC) biasa ditanam pada saat tanaman karet berada pada usia di bawah 5 tahun (Wahab, 2001). Tauseef et al. (2012) menyatakan keragaman jenis vegetasi tanaman di bawah naungan salah satunya dipengaruhi oleh umur dan kondisi tajuk tanaman utama. Joshua dan Joseph. (2015) menyatakan bahwa tanaman vegetasi di bawah tegakan perkebunan karet (umur 5 tahun setelah tanam) dapat meningkatkan kesuburan tanah. Kelembaban dan aktivitas mikrobia dapat menjaga respirasi tanah. Bahan organik, nitrogen total dan nutrien seperti $\mathrm{K}, \mathrm{Ca}$ dan $\mathrm{Mg}$ dapat meningkat ketika tidak ada pemberantasan gulma. Program pengendalian gulma diupayakan dengan cara yang tepat untuk memperoleh output yang mendukung usaha produktif terintergrasi dengan sektor peternakan. Oleh karena itu diperlukan identifikasi lebih lanjut tingkat keragaman vegetasi ditinjau dari jenis gulma yang tumbuh pada setiap fase umur tanaman perkebunan yang dapat dimanfaatkan sebagai hijauan pakan ternak ruminansia.

Berdasarkan uraian diatas maka dilakukan explorasi kondisi lingkungan area perkebunan dan identifikasi jenis-jenis vegetasi gulma yang 
tumbuh di bawah naungan perkebunan karet pada kelompok tanaman belum menghasilkan (TBM) umur 1-5 tahun.

\section{Materi dan Metode}

Materi penelitian

Alat yang digunakan dalam penelitian adalah hagameter, lux meter 4 in 1 , termometer, kamera untuk dokumentasi gulma, meteran, penggaris, tali rafia, kantong koran, staples, spidol, keranjang plastik, plastik, patok, label, timbangan digital, dan software sexi-FS.

Penelitian dilakukan di PTPN IX Kebun Getas yang berada pada ketinggian antara 200$800 \mathrm{~m}$ dpl. Karakteristik tanah adalah aluvial, regosol, mediteran latosol, andosol, dan grumosol dengan $\mathrm{pH}$ antara 6-7, struktur tanah remah (Santosa, 2017). Explorasi kondisi lingkungan area perkebunan dan pengukuran komposisi botani gulma dilakukan pada kelompok TBM umur 1-2, 3-4, dan 5-6 tahun.

Pengamatan Kondisi Lingkungan

Pengamatan kondisi lingkungan gulma area masing-masing TBM meliputi faktor naungan, intensitas cahaya, suhu, kecepatan angin, dan kelembaban. Persentase naungan dengan menggunakan alat hagameter dan program komputer (software) Spatially Explicite Individual-based Forest Simulator (SEXI-FS). Pengukuran intensitas cahaya, suhu, kecepatan angin dan kelembaban dengan alat lux meter 4 in 1 lutron LM-8000.

\section{Pengukuran Komposisi Botani Gulma}

Pengukuran dominasi tanaman menggunakan metode line intercept transect menurut Moody et al. (1984). Dominasi tanaman dilakukan pada setiap kelompok TBM. Teknik tersebut dilakukan dengan jalur/transect sepanjang $30 \mathrm{~m}$ menggunakan tali rafia. Jalur tersebut dibagi ke dalam interval-interval $(1$ interval $=5 \mathrm{~m})$. Setiap interval mewakili satu unit contoh. Semua tumbuhan yang tersinggung dengan garis transect baik terletak dibawah maupun diatas garis diamati dan dicatat. Pengambilan data dilakukan sebanyak tiga kali ulangan di tempat yang berbeda secara representatif terhadap luas area. Metode identifikasi spesies gulma berdasarkan Weed identification oleh Naidu (2012) serta pencarian di website dan diklasifikaskan menjadi 4 kelompok hijauan yaitu rumput, legum, forb dan browse.

Analisis data

Data hasil penelitian kondisi lingkungan dianalisis menggunakan rancangan acak lengkap (RAL) pola searah dan uji lanjut signifikan menggunakan Duncant's Multiple Range Test (DMRT) (Gomez dan Gomez, 1984). Data botani hasil summed dominance ratio (SDR) ditabulasi untuk mendapatkan persentase komposisi botani.

\section{Hasil dan Pembahasan}

Naungan Tanaman Pohon Karet

Perkebunan karet dengan tanaman utama pohon karet akan membentuk naungan atau tajuk yang mempengaruhi persentase cahaya matahari yang menembus ke vegetasi dibawahnya. Naungan yang terbentuk digambarkan dengan analisis ruang horizontal dengan software sexi-FS. Analisis ruang horizontal tersebut pada Gambar 1.

Hasil analisis ruang horizontal pada TBM 1-2 menunjukkan sebaran potensi cahaya terdiri dari putih $100 \%$ dan abu-abu muda $97,5 \%$ (naungan sangat ringan). Analisis tutupan tajuk sebesar $3,52 \%$, menunjukkan cahaya matahari masih dapat mencapai vegetasi dibawah perkebunan karet sebesar 96,48\%. Hasil analisis ruang horizontal pada TBM 3-4 yaitu sebaran potensi cahaya terdiri dari putih $100 \%$ (tdk ada naungan), abu-abu muda $80-90 \%$ (naungan ringan), abu-abu tua (sela antar pohon) $50-60 \%$, abu-abu tua gelap (pojok kiri bawah), 42,5\% (naungan cukup berat), gelap (pojok kiri atas) 21\% (naungan berat) ini karena datanya menunjukkan lebar dan tebal tajuk yg besar dan itu juga berimpit sehingga naungannya kuat/berat di sisi pojok kiri atas. Analisis tutupan tajuk sebesar 59,57\%, menunjukkan cahaya matahari masih dapat mencapai vegetasi dibawah perkebunan karet sebesar 40,43\%. Analisis ruang horizontal pada TBM 5-6 yaitu sebaran potensi cahaya terdiri dari abu-abu muda $88 \%$ (naungan ringan), abuabu tua 68-73\%, abu-abu tua gelap 46-57\%. Analisis tutupan tajuk sebesar 98,20\%, menunjukkan cahaya matahari masih dapat mencapai vegetasi dibawah perkebunan karet sebesar $1,80 \%$. Hasil analisis ruang horizontal dan tutupan tajuk menunjukkan bahwa semakin 
bertambah umur tanaman karet, maka tutupan

tajuk yang terbentuk semakin besar dan rapat.

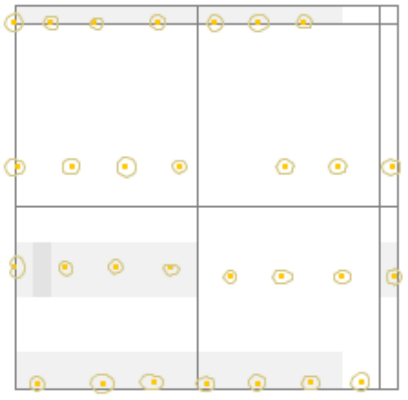

(a)

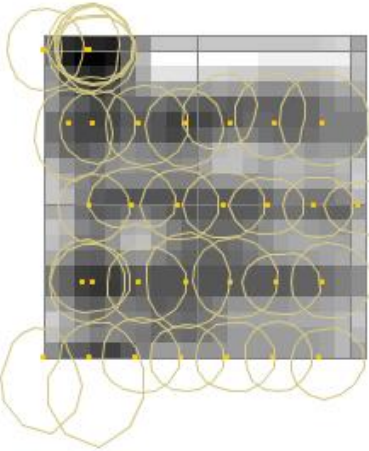

(b)

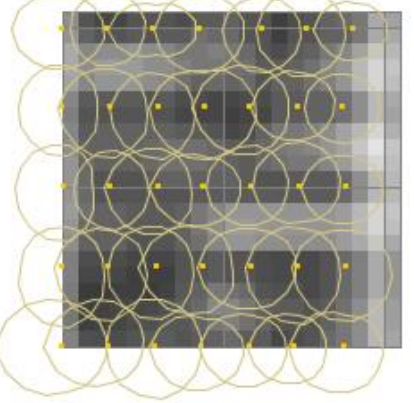

(c)

Gambar 1. Analisis ruang horizontal tutupan tajuk perkebunan karet (a) TBM 1-2, (b) TBM 3-4, (c) TBM 5-6 tahun

Tutupan tajuk umur tanaman karet 1-5 tahun 3,52-98,20\%, data tersebut menunjukkan bahwa umur tanaman karet 5 tahun merupakan tutupan tajuk yang hampir menutup akses cahaya matahari sehingga vegetasi gulma yang terbentuk tahan akan naungan. Oleh karena itu, kondisi naungan yang cukup berat terjadi di sebagian besar masa hidup tanaman karet dan kelapa sawit, sehingga peluang untuk penanaman hijauan pakan ternak produktif hanya pada masa awal dan akhir yaitu sekitar tujuh tahun (Ibrahim, 2003). Transmisi cahaya hasil penelitian Chong et al. (1997) sebesar 62$82 \%$ untuk tanaman belum menghasilkan, sedangkan pada tanaman menghasilkan relatif konstan sebesar 18\% (hanya berbeda pada periode Januari - Maret karena ada pada musim kemarau, daun rontok). Jika dibandingkan dengan literatur maka terdapat perbedaan. Hal tersebut dikarenakan pada hasil penelitian menggunakan tanaman karet belum menghasilkan umur 1-5 tahun.

Intensitas cahaya matahari, suhu, kelembaban udara, dan kecepatan angin

Hasil pengukuran intensitas cahaya, suhu, kelembaban, dan kecepatan angin pada level umur tanaman karet di lahan perkebunan terdapat pada Tabel 1 .

Tabel 1. Hasil pengamatan intensitas cahaya, suhu, kelembaban, dan kecepatan angin pada lahan perkebunan karet

\begin{tabular}{lrrr}
\hline \multirow{2}{*}{ Parameter } & \multicolumn{3}{c}{ Lahan Perkebunan Karet } \\
\cline { 2 - 4 } & TBM 1-2 & TBM 3-4 & \multicolumn{1}{c}{ TBM 5-6 } \\
\hline Intensitas cahaya (lux) & $15.780 \pm 749,53^{\mathrm{c}}$ & $6.115 \pm 190,91^{\mathrm{b}}$ & $1.043 \pm 68,58^{\mathrm{a}}$ \\
Suhu $\left({ }^{\mathrm{o}} \mathrm{C}\right)$ & $35,10 \pm 0,56^{\mathrm{c}}$ & $32,30 \pm 0,14^{\mathrm{b}}$ & $31,10 \pm 0,28^{\mathrm{a}}$ \\
Kelembaban udara (\%) & $41,10 \pm 0,14^{\mathrm{a}}$ & $56,50 \pm 0,42^{\mathrm{b}}$ & $64,25 \pm 0,49^{\mathrm{c}}$ \\
Kecepatan angin (m/s) & $2,60 \pm 0,28^{\mathrm{b}}$ & $2,50 \pm 0,14^{\mathrm{b}}$ & $0,85 \pm 0,21^{\mathrm{a}}$ \\
\hline a,b,c superskrip yang berbeda pada baris yang sama menunjukkan perbedaan yang nyata $(\mathrm{P}<0,05)$
\end{tabular}

Hasil analisis statistik menunjukkan bahwa terdapat pengaruh nyata $(\mathrm{P}<0,05)$ naungan pohon karet terhadap intensitas cahaya matahari, suhu, kelembaban udara, kecepatan angin yang di terima oleh vegetasi dibawahnya. Intensitas cahaya matahari menurun seiring bertambah umur karet pada TBM umur 1-5 tahun dan berkisar dari 1.043-15.780 lux. Menurut Tauseef et al. (2012) intesitas cahaya matahari berpengaruh terhadap jenis gulma yang tumbuh pada setiap umur. Suhartono dan Winara (2018), menambahkan tanaman dengan persentase penutupan tajuk rendah ditemukan jenis gulma beragam dan sebaiknya pada tanaman dengan persentase penutupan tajuk lebih besar lebih didominasi gulma yang tahan naungan.

Suhu menurun seiring bertambah umur karet pada TBM umur 1-5 tahun dan berkisar dari $31-35^{\circ}$ C. Perbedaan Suhu antar kelompok 
TBM dipengaruhi dari penutupan tajuk tanaman karet. Hal ini sesuai dengan Gambar 1. TBM 1-2 memiliki penutupan tajuk 3,52\% sehingga cahaya matahari dapat masuk hingga ke bagian bawah vegetasi. Kelembaban udara naik seiring bertambah umur karet pada TBM umur 1-5 tahun dan berkisar dari 41-64\%. Kecepatan angin menurun seiring bertambah umur karet pada TBM umur 1-5 tahun dan berkisar dari 0,85-6,40 m/s. Menurut Subrata dan Setiawan (2018), bertambahnya umur tanaman karet maka lebar penutupan tajuk semakin bertambah sehingga mempengaruhi kelembaban dan kecepatan angin.

Komposisi Botani Gulma

Komposisi botani gulma yang membentuk vegetasi dibawah naungan perkebunan karet terdiri dari rumput, legum, forb dan browse. Jumlah komposisi botani tersebut disajikan pada Gambar 2.

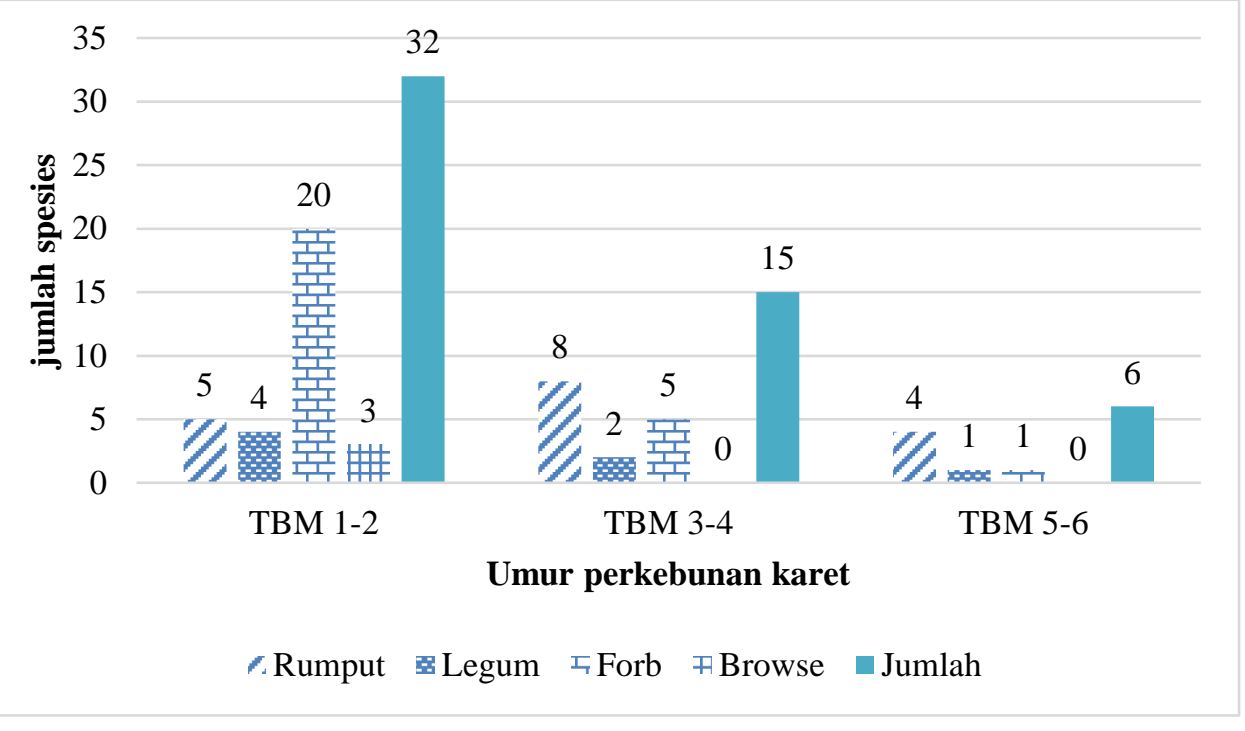

Gambar 2. Komposisi botani gulma pada setiap lahan TBM

Berdasarkan data tersebut menunjukkan bahwa komposisi botani gulma menurun seiring bertambahnya umur tanaman. Hal tersebut dikarenakan intensitas cahaya yang dapat menembus naungan tanaman karet menurun seiring bertambah umur tanaman karet. Hasil penelitian Syahputra et al. (2011) keragaman vegetasi gulma yang tumbuh sebanyak 26 jenis gulma dan gulma dominan yang ditemukan ialah pada kelompok umur muda (1-5 tahun) yaitu Cyperus kyllingia, Axonopus compressus, Clibadium surinames. Perbedaan komposisi botani antar wilayah dapat menyebabkan perbedaan jumlah dan dominasi gulma. Faktor yang mempengaruhi pertumbuhan dan perkembangan setiap jenis gulma berbeda - beda dan agroekologi, serta tindakan budidaya yang berbeda akan menetukan jenis gulma dominan yang berbeda pula (Simangunsong et al., 2018).

Komposisi botani gulma yang membentuk vegetasi dibawah naungan perkebunan karet umur 1-2 tahun (TBM 1-2) terdiri berbagai spesies. Komposisi botani tersebut disajikan pada Tabel 2.

Berdasarkan data tersebut menunjukkan bahwa gulma perkebunan karet umur 1-2 tahun terdiri dari 32 jenis spesies. Keanekaragaman jenis gulma di perkebunan karet TBM 1-2 terdiri dari rumput, legume, forb dan browse. Adapun Gulma yang mendominasi vegetasi tersebut adalah Calopogonium mucunoides Desv, Centrocema pubescens Benth, Setaria plicata (Lamk) T. Cooke, Momordica balsamina, dan Synedrella nodiflora L. Gaertn. Keanekaragaman gulma merupakan salah satu indikator bahwa lingkungan dengan intensitas cahaya tanpa naungan adalah faktor pendukungnya. Nilai summed domination ratio (SDR) digunakan untuk menentukan dominasi jenis tumbuhan terhadap jenis tumbuhan lainnya dari pengaruh lingkungan (Tauseef et al., 2012). 
Tabel 2. Keragaman vegetasi gulma perkebunan karet umur TBM 1-2

\begin{tabular}{|c|c|c|c|c|}
\hline No & Famili & Nama Ilmiah & $\operatorname{SDR}(\%)$ & Rank \\
\hline \multicolumn{5}{|c|}{ Rumput } \\
\hline 1 & Poaceae & Paspalum conjugatum & 2,95 & 14 \\
\hline 2 & Poaceae & Cyrtococcum oxyphyllum & 5,10 & 6 \\
\hline 3 & Poaceae & Setaria plicata (Lamk) T. Cooke & 6,56 & 3 \\
\hline 4 & Poaceae & Urochloa mutica & 1,72 & 25 \\
\hline 5 & Poaceae & Cynodon dactylon & 3,20 & 13 \\
\hline \multicolumn{5}{|c|}{ Legum } \\
\hline 6 & Fabaceae & Mucona bracteata & 3,96 & 9 \\
\hline 7 & Fabaceae & Mimosa pudica $L$. & 2,89 & 15 \\
\hline 8 & Fabaceae & Calopogonium mucunoides Desv & 8,26 & 1 \\
\hline 9 & Fabaceae & Centrocema pubescens Benth & 7,49 & 2 \\
\hline \multicolumn{5}{|c|}{ Forb } \\
\hline 10 & Amaranthaceae & Amaranthus viridis & 0,80 & 32 \\
\hline 11 & Asteraceae & Tridax procumbens $L$. & 2,21 & 21 \\
\hline 12 & Asteraceae & Crassocephalum crepidioides (Benth.) S. Moore & 2,28 & 20 \\
\hline 13 & Asteraceae & Agerantum conyzoides & 4,90 & 8 \\
\hline 14 & Capparidaceae & Cleome rutidosperma $D C$ & 5,61 & 5 \\
\hline 15 & Commelinaceae & Cyanotis axillaris & 1,08 & 30 \\
\hline 16 & Commelinaceae & Commelina diffusa & 2,83 & 16 \\
\hline 17 & Convolvulaceae & Ipomoea triloba $L$. & 3,32 & 12 \\
\hline 18 & Convolvulaceae & Ipomea batatas & 3,80 & 10 \\
\hline 19 & Cucurbitaceae & Momordica balsamina & 6,48 & 4 \\
\hline 20 & Cyperaceae & Cyperus kyllingia Endl. & 2,58 & 18 \\
\hline 21 & Euphorbiaceae & Phyllanthus niruri L. & 1,35 & 27 \\
\hline 22 & Euphorbiaceae & Euphorbia hirta $L$. & 1,78 & 24 \\
\hline 23 & Euphorbiaceae & Euphorbia heterophylla L. & 2,15 & 22 \\
\hline 24 & Linderniaceae & Lindernia crustacea (L.) F. Muell. & 1,09 & 29 \\
\hline 25 & Passifloraceae & Passiflora foetida $L$ & 0,86 & 31 \\
\hline 26 & Piperaceae & Paperomia pellucida (L.) H.B.\&K. & 2,44 & 19 \\
\hline 27 & Rubiaceae & Spermacoce exilis & 1,36 & 26 \\
\hline 28 & Rubiaceae & Borreria latifolia (Aunl) K. Sch & 3,32 & 11 \\
\hline 29 & Sterculiaceae & Melochia concatenata $L$ & 2,62 & 17 \\
\hline \multicolumn{5}{|c|}{ Browse } \\
\hline 30 & Asteraceae & Synedrella nodiflora L. Gaertn & 4,99 & 7 \\
\hline 31 & Malvaceaea & Urena lobata $L$ & 1,97 & 23 \\
\hline 32 & Verbenaceae & Stachytarphea jamaicensis & 1,27 & 28 \\
\hline
\end{tabular}

Komposisi botani gulma yang membentuk vegetasi dibawah naungan perkebunan karet
TBM 3-4 terdiri berbagai spesies. Komposisi botani tersebut disajikan pada Tabel 3 . 
Tabel 3. Keragaman vegetasi gulma perkebunan karet TBM 3-4

\begin{tabular}{|c|c|c|c|c|}
\hline No. & Famili & Nama Ilmiah & $\operatorname{SDR}(\%)$ & Rank \\
\hline \multicolumn{5}{|c|}{ Rumput } \\
\hline 1 & Poaceae & Cyrtococcum acrescens (Trin.) Stapf & 24,85 & 1 \\
\hline 2 & Poaceae & Axonopus compressus (Swartz) Beauv & 7,69 & 4 \\
\hline 3 & Poaceae & Digitaria adscendens (H.B.K.) Henr & 5,03 & 7 \\
\hline 4 & Poaceae & Cynodon dactylon & 4,14 & 12 \\
\hline 5 & Poaceae & Setaria plicata (Lamk) T. Cooke & 2,15 & 15 \\
\hline 6 & Poaceae & Urochloa mutica & 4,97 & 8 \\
\hline 7 & Poaceae & Paspalum conjugatum Ber. & 4,49 & 10 \\
\hline 8 & Poaceae & Imperata cylindrica (Linn.) P. Beauv & 3,51 & 13 \\
\hline \multicolumn{5}{|c|}{ Legum } \\
\hline 9 & Fabaceae & Centrocema pubescens Benth & 8,60 & 2 \\
\hline 10 & Fabaceae & Calopogonium mucunoides Desv & 7,11 & 5 \\
\hline \multicolumn{5}{|c|}{ Forb } \\
\hline 11 & Acanthaceae & Asystasia gangetica & 2,97 & 14 \\
\hline 12 & Asteraceae & Mikania micrantha H.B.K & 4,81 & 9 \\
\hline 13 & Asteraceae & Hellianthus annuss $L$. & 8,32 & 3 \\
\hline 14 & Convolvulaceae & Ipomoea triloba & 7,08 & 6 \\
\hline 15 & Euphorbiaceae & Phyllanthus niruri L. & 4,28 & 11 \\
\hline
\end{tabular}

Hasil penelitian menunjukkan bahwa gulma perkebunan karet umur 3-4 tahun terdiri dari 15 jenis spesies. Keanekaragaman jenis gulma perkebunan karet umur 3 - 4 terdiri dari rumput (Cyrtococcum acrescens (Trin.) legum (Centrocema pubescens Benth, Calopogonium mucunoides Desv), dan forb (Hellianthus annuss L). Jika dibandingkan tanaman yang tumbuh di bawah tanaman kelapa sawit umur 3 tahun didominasi oleh Paspalum conjugatum (45,54\%) (Daru et al., 2014).

Komposisi botani gulma yang membentuk vegetasi dibawah naungan perkebunan karet umur 5 - 6 tahun terdiri berbagai spesies. Komposisi botani disajikan pada Tabel 4

.Tabel 4. Keragaman vegetasi gulma perkebunan karet TBM 5-6

\begin{tabular}{|c|c|c|c|c|}
\hline No. & Famili & Nama Ilmiah & $\operatorname{SDR}(\%)$ & Rank \\
\hline \multicolumn{5}{|c|}{ Rumput } \\
\hline 1 & Poaceae & Oplismenus burmanii (Retz.) Beauv & 20,53 & 2 \\
\hline 2 & Poaceae & Paspalum scrobiculatum & 8,76 & 6 \\
\hline 3 & Poaceae & Urochloa mutica & 14,52 & 3 \\
\hline 4 & Poaceaea & Cyrtococcum oxyphyllum & 35,92 & 1 \\
\hline \multicolumn{5}{|c|}{$\begin{array}{l}\text { Legum } \\
\end{array}$} \\
\hline 5 & Fabaceae & Leucocephala leucocephala & 11,14 & 4 \\
\hline \multicolumn{5}{|c|}{ Forb } \\
\hline 6 & Acanthaceae & Asystasia gangetica & 9,15 & 5 \\
\hline
\end{tabular}

Hasil penelitian menunjukkan bahwa gulma perkebunan karet umur 5-6 tahun terdiri dari 6 jenis spesies. Keanekaragaman spesies gulma di TBM 5-6 terdiri dari rumput (Oplismenus burmanii (Retz.) Beauv, Paspalum scrobiculatum, Urochloa mutica, Cyrtococcum oxyphyllum), legum (Leucocephala leucocephala), dan forb (Asystasia gangetica). Gulma yang mendominasi vegetasi tersebut adalah Cyrtococcum oxyphyllum (rumput), 
Leucocephala leucocephala (legum), dan Asystasia gangetica (forb). Menurut Subrata dan Setiawan (2018), bertambahnya umur tanaman karet maka lebar tajuk akan mempengaruhi komposisi botani yang terdapat dibawah naungan tanaman utama.

Hasil identifikasi jenis gulma yang tumbuh di bawah naungan perkebunan karet pada Tabel 2, 3, dan 4 menunjukan keragaman vegetasi gulma mulai menurun seiring dengan bertambahnya umur tanaman karet. Vegetasi gulma didominasi oleh jenis rerumputan kemudian jenis legum. Selaras dengan penelitian Nuhuyanan (2010) bahwa tanaman rerumputan mendominasi padang rumput alam Kebar Manokwari kemudian jenis legume. Tanaman legume mengintroduksi unsur hara yang dibutuhkan oleh rerumputan. Introduksi legum dapat meningkatkan produksi hijauan segar, bahan kering dan bahan organik dari vegatasi yang berkembang di area padang rumput. Oleh karena itu peranan legum di area perkebunan karet dimungkinankan dapat meningkatkan produksi segar dari tanaman rumput yang tumbuh serta sebagai penyedia unsur hara bagi tanaman utama.

\section{Kesimpulan}

Berdasarkan hasil penelitian disimpulkan gulma perkebunan karet lahan TBM 1-2 memiliki komposisi botani dan potensi tertinggi sebagai pakan ternak ruminansia. Gulma yang mendominasi masing-masing TBM yaitu legum Calopogonium mucunoides, rumput Cyrtococcum acrescens dan Cyrtococcum oxyphyllum.

\section{Ucapan Terimakasih}

Ucapan terimakasih kami sampaikan kepada PTPN IX Kebun Getas yang telah memberikan kesempatan untuk melakukan eksplorasi potensi gulma dan Fakultas Peternakan Universitas Gadjah Mada yang telah memberikan dukungan dalam proses penelitian.

\section{Daftar Pustaka}

Chong DT, Tajuddin I, Samat Abd MS, Stur WW and Shelton HM. 1997. "Stocking rate effects on sheep and forage productivity under rubber in Malaysia," Journal of
Agricultural Science. Cambridge. 128:339-

346.

doi:

https://doi.org/10.1017/S00218596960042 36.

Daru TP, Yulianti A, dan Widodo E. 2014. "Potensi hijauan di perkebunan kelapa sawit sebagai pakan sapi potong di Kabupaten Kutai Kartanegara," Pastura. 3: 94-98.

Gabungan Perusahaan Karet Indonesia (GAPKINDO). 2016. "Tersedia di http://www.gapkindo.org/en/component/c ontent/article/1-artikel/148-luas-

perkebunan-karet-eng.html'. Di akses pada 18 Mei 2020.

Gomez KA and Gomez AA. 1984. "Statictic Procedure for Agricultural Research. Second Edition. An International Rice Research Institute Book. Coryright John and Sons Inc. New York. Toronto.

Ibrahim. 2003. "Strategi Penelitian Hijauan Mendukung Pengembangan Ternak Kambing Potong di Indonesia", WARTAZOA. 13(1) : 1-8.

Joshua A and P Joseph. 2015. "A new weed management approach yo improve soil health in a tropical plantation crop, rubber (Hevea brasiliensis)", Cambridge University Press. 52(1): 36-50.

Moody K, Munroe CE, Lubigan RT and Paller EC. 1984. "Major weeds of the Philippines", Weed Science Society of the Philippines. University of the Philippines at Los Banos College, Laguna, Philippines.

Naidu VSGR. 2012. "Weed Identification", Directorate of Weed Science Research. Jabalpur. India.

Nuhuyanan LE. 2010. "Pengaruh Pemupukan dan Introduksi Legum terhadap Kualitas Padang Rumput Alam di Kebar Kabupaten Manokwari". Jurnal Ilmu Peternakan, 5(1): 13-19.

Santosa WH. 2017. "Profil PT. Perkebunan Nusantara IX Kebun Getas-Salatiga". PTPN IX Getas - Salatiga, Jawa Tengah.

Simangunsong YP, Zaman S dan Guntoro D. 2018. "Manajemen Pengendalian Gulma Perkebunan Kelapa Sawit (Elaeis guineensis Jacq.): Analisis Faktor- faktor Penentu Dominansi Gulma di Kebun Dolok Ilir, Sumatera Utara", Buletin 
Agrohortikultura. 6(2):189-196. doi: 10.29244/agrob.6.2.189-196.

Soejono AT, Tohari, Pudjorinto dan Kastono AR. 2000. "Inventarisasi Gulma di Kebun PT. Pagilaran Kabupaten Batang”, PT. Pagilaran-Universitas Gadjah Mada. Yogyakarta.

Subrata BAG dan Setiawan BA. 2018. "Keragaman vegetasi gulma di bawah tegakan pohon karet (Hevea Brasiliensis) pada umur dan arah lereng yang berbeda di PTPN IX Banyumas", Jurnal Ilmiah Pertanian. 14(2): 1-13. doi: 10.31849/jip.v14i2.710.

Suhartono dan Winara A. 2018. "Keragaman dan Potensi Pemanfaatan Jenis Gulma pada Agroforestri Jati (Tectona grandis L.f) dan Jalawure (Tacca leontopetaloides (L) Kuntz)", Jurnal Penelitian Hutan dan Konservasi Alam. 15(2): 65-77.
Syahputra E, Sarbino dan Dian S. 2011. “Weeds Assessment di Perkebunan Kelapa Sawit Lahan Gambut", Jurnal Perkebunan dan Lahan Tropika. 1: 37-42.

Tauseef M, Ihsan F, Nazir W and Farooq J. 2012. "Weed flora and importance value index (IVI) of the weeds in cotton crop fields in the region of Khanewal, Pakistan", Pakistan Journal Weed Science. Research. 18(3): 319-330.

Wahab HA. 2001. "Forages in oil palm and rubber plantation in Malaysia". In: Moog, F. A.; Reynolds, S. G.; Maaruf, K. (Eds.), Proc. 7th Meet. Reg. Work. Group on Grazing and Feed Resources, Forage Dev. in South-East Asia: Strategies and Impacts, FAO, Indonesia. 